\title{
Atmospheric deposition of toxics onto the Seine Estuary, France: example of polycyclic aromatic hydrocarbons
}

A. Motelay-Massei ${ }^{1}$, D. Ollivon ${ }^{2}$, B. Garban ${ }^{2}$, and M. Chevreuil ${ }^{1}$

${ }^{1}$ Laboratoire de Géologie Appliquée, UMR Sisyphe 7619, Université Pierre et Marie Curie, 4 place Jussieu, case 122, 75252 Paris cedex 05, France

${ }^{2}$ Laboratoire Hydrologie et Environnement, Ecole Pratique des Hautes Etudes, UMR Sisyphe 7619, Université Pierre et Marie Curie, 4 place Jussieu, case 122, 75252 Paris cedex 05, France

Received: 23 May 2002 - Accepted: 10 July 2002 - Published: 17 September 2002

Correspondence to: A. Motelay-Massei (motelay@biogeodis.jussieu.fr)
$2,1351-1369,2002$

Atmospheric deposition of PAHs in the Seine Estuary,

France

A. Motelay-Massei et al.

Title Page

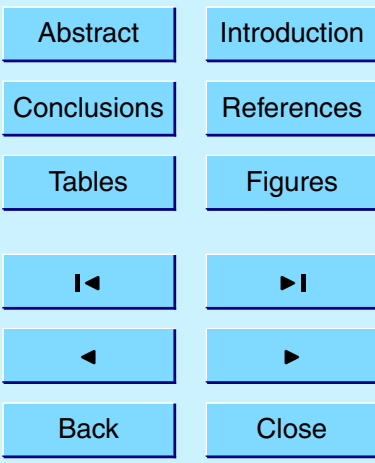

Full Screen / Esc

Print Version

Interactive Discussion

(C) EGS 2002 


\section{Abstract}

Concentrations of Polycyclic Aromatic Hydrocarbons (PAH) were measured in precipitation samples on a weekly basis between March and October 2001, at four sites in the Seine Estuary (France). Mean concentrations of total PAHs ( $\Sigma 14$ PAHs) ranged from

538 to $141 \mathrm{ng} \mathrm{L}^{-1}$. Fluoranthene, phenanthrene and pyrene were the dominant PAH compounds and were detected in each sample. The six potential carcinogenic PAHs accounted for 20 to $25 \%$ of the total PAH concentration in bulk deposition. The PAH signatures in bulk (wet and dry) deposition and surface water were also compared to investigate source/sink relationships. Seasonal patterns were observed with maximum loading occurring during the colder months of the studied period (March and April). Mean values of daily flux reported for $\Sigma 14 \mathrm{PAHs}$ ranged from 108 to $267 \mathrm{ng} \mathrm{m}^{-2} \mathrm{~d}^{-1}$. Spatial influences were also observed, indicating both localized and long-range atmospheric source inputs (controlled by hydroclimatic parameters).

\section{Introduction}

15 The evolution of industry and the increase of population have resulted in deep changes in quality of our environment. Nowadays much more often the attention of analysts is focused on the presence of organic pollutants in precipitation. These studies showed the presence of more than 600 chemicals like polycyclic aromatic hydrocarbons, organohalogen compounds, pesticides or polychlorinated biphenyls for example in the most of countries (Grynkiewicz et al., 2002; Kawamura and Kaplan, 1986; Kiss et al., 1997; Leuenberger et al., 1988; Manoli et al., 2000; Simcik et al., 2000). Atmospheric inputs (wet and dry) play a significant role in semivolatile chemicals cycling (Offenberg and Baker, 1997). Then, atmospheric depositions represent respectively $90 \%, 78 \%$ and $58 \%$ of inputs of organic contaminants to the surface of Superior, Michigan and Huron Lakes (Strachan and Eisenreich, 1988). Atmospheric deposition consists of both wet (vapour and particle washout) and dry (particle settling). Polycyclic aromatic hydrocar-
ACPD

$2,1351-1369,2002$

\section{Atmospheric deposition of PAHs in the Seine Estuary, France}

A. Motelay-Massei et al.

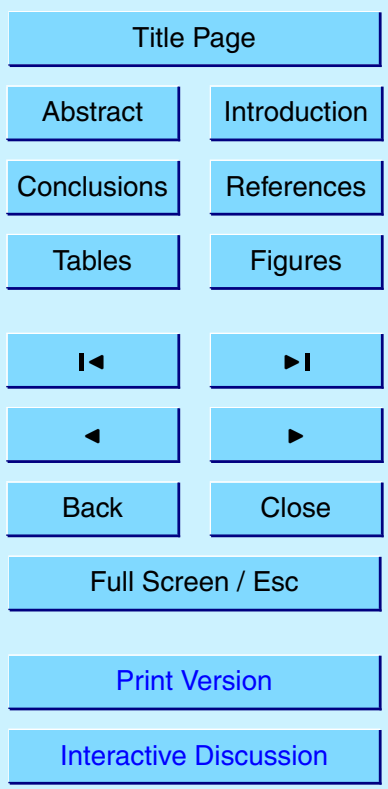


bons (PAHs) are class of compounds referred to as semi-volatile organic contaminants (SOCs). There are two to eight ring compounds of great environmental concern because of their carcinogenic and mutagenic properties (Menzie et al., 1992; Tsai et al., 1995; Valberg et al., 1996; Valerio et al., 1992). PAHs are formed primarily dur5 ing incomplete combustion of fossil fuels and wood. Major sources of PAHs to urban atmosphere can include automobile traffic, home heating, municipal incinerators and industrial emissions. Despite their production in urban and industrial sites, PAHs occur at high concentrations in rural areas due to their persistence and ability to be transported over long distances.

10 The aim of this investigation was to obtain information about the occurrence of organic trace components in precipitation in the Seine Estuary. It was also of interest to investigate the spatial and temporal variability of PAHs in the bulk (wet and dry) deposition occurring in the estuary region and to estimate PAH deposition flux. Moreover, it seemed to be interesting to check the potential differences between the various sites 15 (urban, industrial or rural).

\section{Experimental}

\subsection{Sampling sites}

Precipitation samples were collected at four locations in the Seine Estuary. Figure 1 shows a map of the sampling sites. These one were chosen so as to be able to establish the effect of sampling location on the contents of the PAHs analysed. Historically, the Seine Estuary, like most of European estuaries, has been the centre of the development of an important economic activity. Intensive development of human activities (petrochemical industries, thermal power-station, incinerators, domestic heating, automobile traffic) in the alluvial plains and in the estuary is the cause of the important flow
ACPD

$2,1351-1369,2002$

\section{Atmospheric deposition of PAHs in the Seine Estuary, France}

A. Motelay-Massei et al.

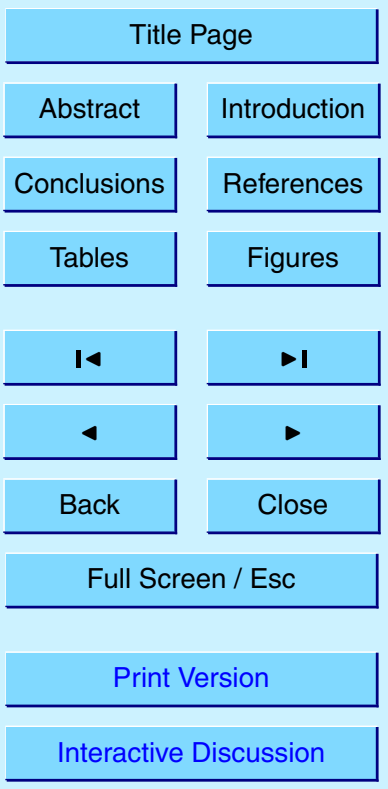

Site 1 Rouen, representative of urban area influenced by heavy traffic. 
Site 2 Notre-Dame de Gravenchon (NDG), representative of urban area, subjected to an industrial pressure.

Site 3 Le Havre, representative of typical industrial areas in the estuary.

Site 4 Evreux, rural site

5 Sites were chosen to be as far away as possible from buildings, large trees and roads to keep contamination at a minimum.

\subsection{Sampling procedure and analytical methods}

Bulk atmospheric deposition (wet and dry) were collected weekly from March to October 2001 (88 samples). Thus it is possible to pinpoint qualitative and quantitative 10 changes in the occurrence of PAHs. Moreover, the weekly sampling period makes it possible to avoid the uncertainties. A longer sampling period could be especially detrimental to PAH deposition measurements, as heat and light may cause evaporation, revolatilization and deterioration of the $\mathrm{PAH}$ species.

Meteorological data (temperature, precipitation amount and wind direction) were obtained from the nearest Mto France stations. Three meteorological stations at the sampling stations were used. The same station was used to Le Havre and NDG because of their climatic similarities. As regards typical circulation of air masses, the prevailing wind direction was generally West and Northwest (Fig. 2). Meteorological data on the sampling period are summed up in Table 1.

20 Samples were collected using a simple apparatus consisting of a $25 \mathrm{~L}$ aluminium bottle equipped with a polished stainless steel funnel (collection area $=0.36 \mathrm{~m}^{2}$ ). After a sampling period, the receiving bottles are brought to the laboratory for PAHs analysis and also for the analysis of organochlorine contaminants. On the total volume of precipitation, 3.6 $\mathrm{L}$ were extracted. Fallout extractions were performed using a liquid-liquid 25

technique. Samples were shaken 3 times and for $20 \mathrm{~min}$ in a glass bottle, using $100 \mathrm{~mL}$ of a hexane/methylene chloride mixture $(\mathrm{v} / \mathrm{v} 85 / 15)$ for each litre of sample (Ollivon et
ACPD

2, 1351-1369, 2002

\section{Atmospheric deposition of PAHs in the Seine Estuary, France}

A. Motelay-Massei et al.

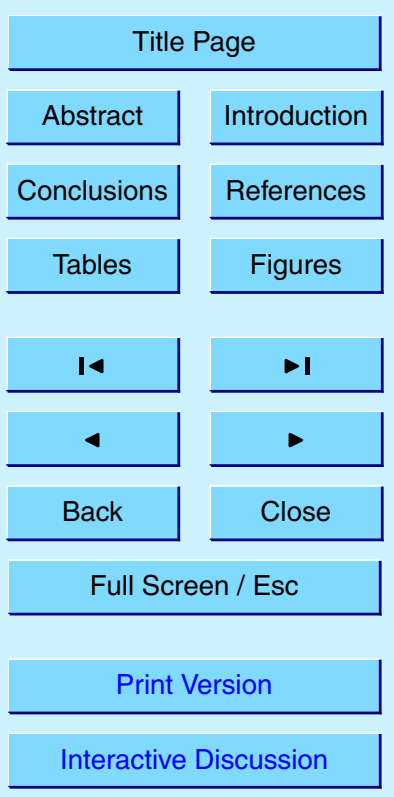

(C) EGS 2002 
al., 1999). Extracts were combined and reduced to about $3 \mathrm{ml}$ on a rotary evaporator; after removal of sulphides by adding mercury, no further purification was performed. As elution solvent for HPLC is acetonitrile/water, hexane had to be exchanged with acetonitrile. For this purpose, methylene chloride and acetonitrile were added to the 5 reduced extract in a 3/1/1 proportion for hexane/methylene chloride/acetonitrile, respectively. Then the mixture was concentrated on a rotary evaporator to about $0.5 \mathrm{~mL}$ and subjected to liquid chromatographic analysis.

A solution of a standard mixture (PAH-Mix 9 in acetonitrile from Dr. Ehrenstorfer $\mathrm{GmbH}$, Augsburg, Germany) containing the 16 PAHs recommended by the EPA method 10 \# 610 was used: naphthalene (NAP), acenaphthalene (ACY), acenaphthene (ACE), fluorene (FL), phenanthrene (PHE), anthracene (ANT), fluoranthene (FTH), pyrene (PYR), benz(a)anthracene (BAA), chrysene (CHR), benzo(b)fluoranthene (BBF), benzo(k)fluoranthene (BKF), benzo(a)pyrene (BAP), dibenz(a,h)anthracene (DBA), benzo(g,h,i)perylene (BGP), indeno(1,2,3-cd)pyrene (IND). When extracted in the same conditions, the recovery efficiency ranged from $91 \%$ to $113 \%$.

Chromatography of the extracts was performed on a Dionex 4500i chromatograph, equipped with a Vydac 201TP5415 column and two detectors, UV/visible and fluorimetric. The instrumental conditions have been described more precisely elsewhere (Ollivon et al., 1995). Replicate analyses of standards gave relative standard deviation (RSD) from $\pm 4 \%$ to $\pm 8 \%$, and detection limits, in our analytical conditions, ranged from 0.06 to $0.6 \mathrm{ng} \mathrm{L}^{-1}$, depending on the $\mathrm{PAH}$ analysed. Blanks extracted in the same conditions were below detection limits and results were displayed without blank correction. Naphtalene, which is highly volatile, and acenaphthalene, which is weakly fluorescent, were not quantified; therefore, "total PAHs" included 14 compounds.

\section{Results and discussion}

The following results bring together data from 5 March to 1 October 2001. Analytical results indicated that polynuclear aromatic hydrocarbons were present in precipitation

ACPD

2, 1351-1369, 2002

\section{Atmospheric deposition of PAHs in the Seine Estuary, France}

A. Motelay-Massei et al.

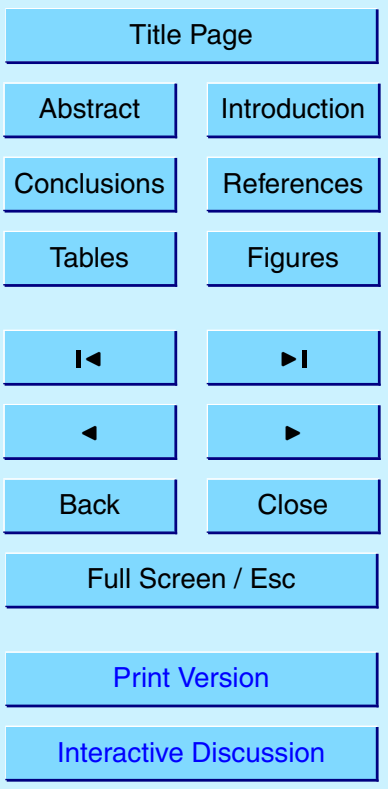

(C) EGS 2002 
in frequent basis. For the 88 samples, concentrations were indeed greater than the limit of detection (L.D.).

ACPD

2, 1351-1369, 2002

\subsection{Bulk deposition concentrations}

Concentrations of selected PAHs measured in the Seine Estuary are summarized in

5 Table 2. These values showed bulk deposition, such means both wet and dry deposition. 14 PAHs were identified and quantified. For sum of total PAHs, concentrations ranged from 3.45 to $234 \mathrm{ng} \mathrm{L}^{-1}$ at Evreux, from 8.7 to $672 \mathrm{ng} \mathrm{L}^{-1}$ at Le Havre, from 3.45 to $129 \mathrm{ng} \mathrm{L}^{-1}$ at Rouen and from 9.6 to $184 \mathrm{ng} \mathrm{L}^{-1}$ at NDG. Mean concentrations of total PAHs were, respectively, $77.8,141,49.6$ and $38 \mathrm{ng} \mathrm{L}^{-1}$. Usually, levels mea-

10 sured in rainwater of the Seine estuary were close to those reported in the literature. However, their comparison is not easy because (i) measured PAHs may differ and (ii) measurements may concern only wet instead of bulk deposition. Nevertheless, orders of magnitude can be compared. Bulk deposition concentrations of $\Sigma 14$ PAHs in Switzerland were $210 \mathrm{ng} \mathrm{L}^{-1}$ in Spring and $130 \mathrm{ng} \mathrm{L}^{-1}$ in Summer (Leuenberger et al., 1988). Kiss et al. (1997) estimated relatively higher bulk deposition concentrations of PAHs near Lake Balaton in Hungary. Mean values reported for $\Sigma 12$ PAHs were $324 \mathrm{ng} \mathrm{L}^{-1}$ (March to May) and $164 \mathrm{ng} \mathrm{L}^{-1}$ (June to August). Phenanthrene, fluoranthene and pyrene together accounted for $50-65 \%$ of the total PAH concentrations in the precipitation (Fig. 3). The dominance of these three compounds may be explained by their higher water solubility, higher emission rates and/or lower reactivity in atmosphere. The sum of the six potential carcinogenic PAHs $\left(\Sigma P A H_{\text {carc }}\right)$ as described by the International Agency for Research on Cancer (IARC, 2001), i.e. BAA, BBF, BFK, BAP, DBA and IND, was found to be in large amount concentrations at Le Havre, representing $25 \%$ of total PAHs.

25 The PAH signatures in bulk deposition and surface water were compared to investigate source/sink relationships. Figure 4 shows this average signature of the concentrations both in rainwater (Rouen) and in surface water. Surface water concentrations data were taken from Ollivon et al. (1999) in the Seine River. The PAH signature in

\section{Atmospheric deposition of PAHs in the Seine Estuary, France}

A. Motelay-Massei et al.

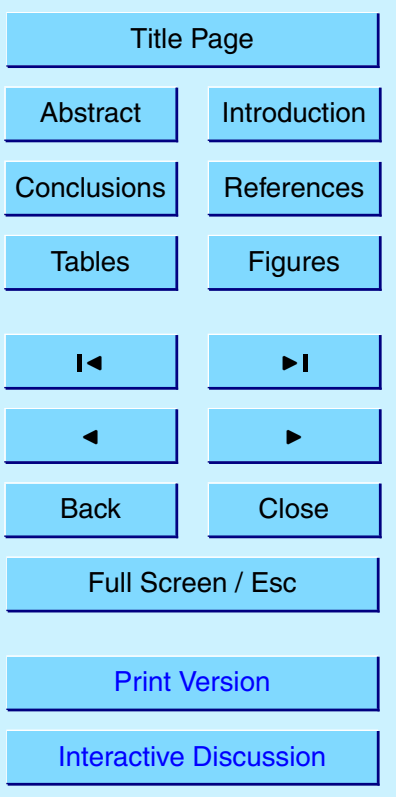

(C) EGS 2002 
surface waters was correlated with the signature of bulk precipitation $\left(r^{2}=0.70\right)$, supporting the hypothesis that atmospheric deposition are among the major PAH sources into surface waters.

\subsection{Bulk deposition fluxes}

5 Highest fluxes were measured in Le Havre precipitations, with flux of $56 \mu \mathrm{g} \mathrm{m}^{-2}$ during the studied period. Fluxes in Rouen and Evreux were, respectively, 30.8 and $28.2 \mu \mathrm{g} \mathrm{m}^{-2}$. The lowest value was found in NDG with $22.7 \mu \mathrm{g} \mathrm{m}^{-2}$. At the four sites, daily fluxes were $0.27 \mu \mathrm{g} \mathrm{m}^{-2} \mathrm{~d}^{-1}, \quad 0.15 \mu \mathrm{g} \mathrm{m}^{-2} \mathrm{~d}^{-1}, \quad 0.13 \mu \mathrm{g} \mathrm{m}^{-2} \mathrm{~d}^{-1}, \quad$ and $0.11 \mu \mathrm{g} \mathrm{m}^{-2} \mathrm{~d}^{-1}$, for Le Havre, Rouen, Evreux, and NDG. Halsall et al. (1997) reported 10 higher bulk deposition fluxes of PAHs in Manchester and Cardiff: median values reported for $13 \mathrm{PAHs}$ were 5.2 and $4.1 \mu \mathrm{g} \mathrm{m}^{-2} \mathrm{~d}^{-1}$, respectively. The lower range obtained in our case may be due to the fact that the sampling period did not include the colder months, during which fluxes are usually known to be greater (Brun et al., 1991; Golomb et al., 1997).

15 As PAH production is associated with anthropogenic activities such as home heating and industry, the distance from potential source may explain the differing observations. The total PAHs deposition fluxes for the studied period were not found to differ significantly between Rouen (urban site) and Evreux (rural site). The latter site is actually located at the periphery of the city of Evreux, more exactly at the North of the town. Prevailing southeasterly winds (Fig. 5) would then indicate that PAHs fluxes measured at this rural site originate the city of Evreux (e.g. essentially home heating and automobile traffic).

NDG seemed to be less affected by PAHs contamination, which phenomenon appears fairly unexpected. One could explain this effect by prevailing northern winds that 25 avoid PAHs fluxes originating the south of NDG (location of the industrial site) to reach the city. Moreover, great chimney height on the industrial site also prevent the town from contaminants deposition: falling of PAHs would then affect neighbouring towns.
ACPD

$2,1351-1369,2002$

\section{Atmospheric deposition of PAHs in the Seine Estuary, France}

A. Motelay-Massei et al.



(C) EGS 2002 
Bulk deposition fluxes of the sum of $14 \mathrm{PAH}$ species decreased in summer when the lowest values reached $43 \mathrm{ng} \mathrm{m}^{-2}$ week $^{-1}$ (Rouen, 10-17 September 2001). At Rouen (Fig. 6), the mean for the heating season was $2766 \mathrm{ng} \mathrm{m}^{-2}$ week $^{-1}$, for the non-heating season was $619 \mathrm{ng} \mathrm{m}^{-2}$ week $^{-1}$, indicating deposition fluxes were higher in cold period 5 than in summer, due to the greater use of fossil fuels and wood for space heating in the colder months.

The seasonal change in deposition total PAH fluxes can be attributed to different phenomena. During the colder months (March and April), large amounts of PAHs are emitted from residential heating (Lohmann et al., 2000; Ollivon et al., 2002.). Moreover

10 the low-temperature driving conditions results in a 4-10 fold increased emission from motor vehicles (Grimmer, 1983). Finally, in addition to the higher emission rates, the meteorological conditions in cold period (lower intensity of sunshine and consequently less efficient photochemical decomposition) favour the increase of PAH concentration in atmosphere and therefore PAH deposition fluxes. Higher deposition of PAHs in win-

15 ter compared to summer has been reported by several investigators, as we already mentioned above. Hart et al. (1993) found the spring:summer ratio of total PAH concentrations in rain in Switzerland to be about 2:1.

\section{Conclusions}

$\mathrm{PAH}$ concentrations in bulk deposition were measured at different sites in the Seine 20 Estuary during the period of March to October 2001. PAHs were present in rain in such levels as to give rise to great concern. The concentrations of PAHs in this study were comparable to the range of concentrations reported for other locations. Bulk depositional fluxes of these contaminants had been directly determined from the data. Le Havre received more atmospheric deposition of PAHs than the other sites, indicat25 ing the influence of industrial activities. Notable seasonal variability in the deposition fluxes of total PAHs was observed. During the heating season there is more deposition. Further, deposition fluxes of PAHs were found to vary spatially in Seine Estuary, likely

ACPD

2, 1351-1369, 2002

\section{Atmospheric deposition of PAHs in the Seine Estuary, France}

A. Motelay-Massei et al.



C) EGS 2002 
due to the location of the site (urban, rural or industrial area) and to the influence of meteorological parameters. Atmospheric deposition appears to be an important phenomenon for the introduction of organic pollutants in terrestrial and aquatic ecosystems (surface- and groundwater).

5 Acknowledgements. Special thanks are expressed to Air Normand for collecting the Evreux and Le Havre samples. The technical help of C. Chesterikoff, J. Rolet and L. Hanselin was highly appreciated. This work was supported by Seine Aval scientific programme and by the "Agence pour l'Environnement et la Maîtrise de l'Energie".

\section{References}

Brun, G. L. H., Howell, G. D., and O'Neill, H. J.: Spatial and temporal patterns of organic contaminants in wet precipitation in Atlantic Canada, Environ. Sci. Technol., 25, 1249-1261, 1991.

Golomb, D., Ryan, D., Underhill, J., Wade, T. and Zemba, S.: Atmospheric deposition of toxics onto Massachusetts bay - II. polycyclic aromatic hydrocarbons, Atmospheric Environment, 31, 9, 1361-1368, 1997.

Grimmer, G.: Profile analysis of polycyclic aromatic hydrocarbons in air, in: Handbook of Polycyclic Aromatic Hydrocarbons, chapter 4, pp. 149-181, Marcel Dekker, New York, 1983.

Grynkiewicz, M., Polkowska, Z., and Namiesnik, J.: Determination of polycyclic aromatic hydrocarbons in bulk precipitation and runoff waters in an urban region (Poland), Atmospheric

20 Environment, 36, 2, 361-369, 2002.

Halsall, C. J., Coleman, P. J. and Jones, K. C.: Atmospheric deposition of polychlorinated dibenzo-p-dioxins / dibenzofurans (PCDD/Fs) and polycyclic aromatic hydrocarbons (PAHs) in two UK cities, Chemosphere, 35, 9, 1919-1931, 1997.

Hart, K. M., Tremp, J., Molnar, E. and Giger, W.: The occurrence and the fate of organic 25 pollutants in the atmosphere, Water, Air, and Soil Pollution, 68, 1/2, 91-112, 1993.

IARC (International Agency for Research on Cancer). http: //www . iarc. fr, 2001.

Kawamura, K. and Kaplan, I. R.: Compositional change of organic matter in rainwater during precipitation events., Atmospheric Environment, 20, 527-535, 1986.

Kiss, G., Gelencser, A., Krivacsy, Z., and Hlavay, J.: Occurrence and determination of organic

ACPD

$2,1351-1369,2002$

\section{Atmospheric deposition of PAHs in the Seine Estuary, France}

A. Motelay-Massei et al.

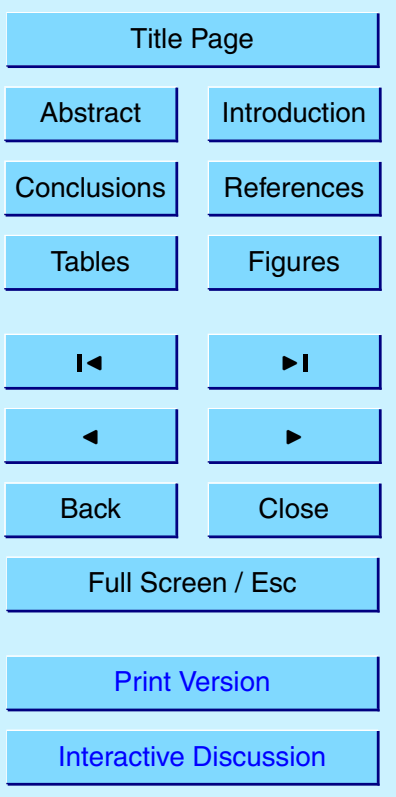

(C) EGS 2002 
pollutants in aerosol, precipitation, and sediment samples collected at Lake Balaton, Journal of Chromatography A, 774, 1/2, 349-361, 1997.

Leuenberger, C., Czuczwa, J., Heyerdahl, E., and Giger, W.: Aliphatic and polycyclic aromatic hydrocarbons in urban rain, snow and fog, Atmospheric Environment, 22, 4, 695-705, 1988.

5 Lohmann, R., Northcott, G. L., and Jones, K. C.: Assessing the contribution of diffuse domestic burning as a source of PCDD/Fs, PCBs, and PAHs to the U.K. Atmosphere, Environ. Sci. Technol., 34, 14, 2892-2899, 2000.

Manoli, E., Samara, C., Konstantinou, I., and Albanis, T.: Polycyclic aromatic hydrocarbons in the bulk precipitation and surface waters of Northern Greece, Chemosphere, 41, 12, 1845$10 \quad 1855,2000$.

Menzie, C. A., Potocki, B. B., and Santodonato, J.: Exposure to carcinogenic PAHs in the environment, Environ. Sci. Technol., 26, 1278-1284, 1992.

Offenberg, J. H. and Baker, J. E.: Polychlorinated biphenyls in Chicago precipitation: Enhanced wet deposition to near-shore Lake Michigan, Environ. Sci. Technol., 31, 1534-1538, 1997.

15 Ollivon, D., Garban, B., and Chesterikoff, A.: Analysis of the distribution of some polycyclic aromatic hydrocarbons in sediments and suspended matter in the river Seine, France, Journal of Water, Air and Soil Pollution, 81, 135-152, 1995.

Ollivon, D., Blanchard, M., and Garban, B.: PAH fluctuations in rivers in the Paris region (France): Impact of floods and rainy events, Water, Air and Soil Pollution, 115, 1-4, 429444, 1999.

Ollivon, D., Blanchoud, H., Motelay-Massei, A., and Garban, B.: Atmospheric deposition of PAHs to an urban site, Paris, France, Atmospheric Environment, 36, 2891-2900, 2002.

Simcik, M. F., Hoff, R. M., Strachan, W. M. J., Sweet, C. W., Basu, I., and Hites, R. A.: Temporal trends of semivolatile organic contaminants in Great Lakes precipitation, Environ. Sci. Technol., 34, 361-367, 2000.

Strachan, W. M. J. and Eisenreich, S. J.: Mass balancing of toxics chemicals in the Great Lakes: the role of atmospheric deposition, International joint commission, Windsor, Ontario, pp. 113, 1988.

Tsai, J. H., Peng, B. H., Lee, D. Z., and Lee, C. C.: PAH characteristics and genotoxicity in the 30 ambient air of a petrochemical industry complex, Environment International, 21, 1, 47-56, 1995.

Valberg, P. A., Drivas, P. J., McCarthy, S., and Watson, A. Y.: Evaluating the health impacts of incinerator emissions, Journal of Hazardous Materials, 47, 1-3, 205-227, 1996.
ACPD

2, 1351-1369, 2002

\section{Atmospheric deposition of PAHs in the Seine Estuary, France}

A. Motelay-Massei et al.

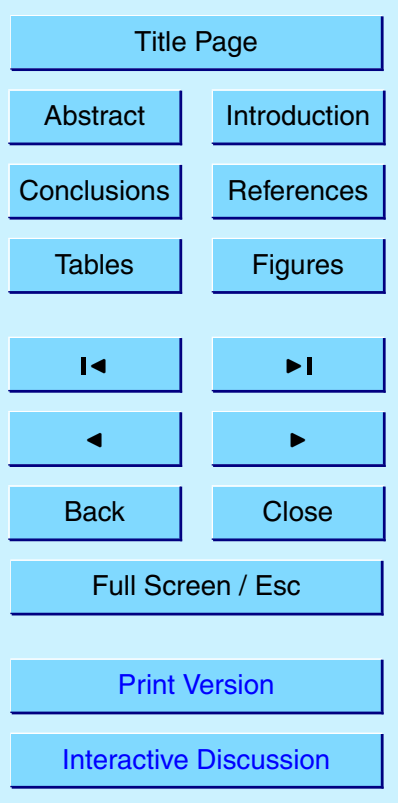


Valerio, F., Brescianini, C., Pala, M., Lazzarotto, A., Balducci, D., and Vincenzo, F.: Sources and atmospheric concentrations of polycyclic aromatic hydrocarbons and heavy metals in two Italian towns (Genoa and La Spezia), The Science of the Total Environment, 114, 4757, 1992.

\section{ACPD}

2, 1351-1369, 2002

Atmospheric deposition of PAHs in the Seine Estuary,

France

A. Motelay-Massei et al.

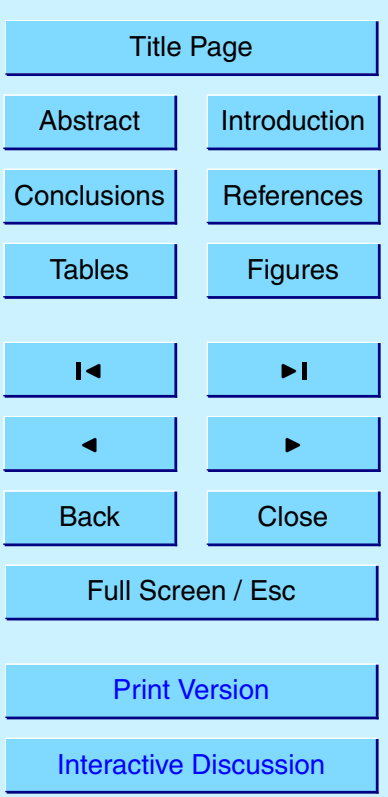




\section{ACPD}

2, 1351-1369, 2002

\section{Atmospheric deposition of PAHs in the Seine Estuary, \\ France}

A. Motelay-Massei et al.

Table 1. Meteorological data during the sampling period at the 3 sites

\begin{tabular}{lccc}
\hline & Le Havre & Rouen & Evreux \\
\hline Mean temperature $\left({ }^{\circ} \mathrm{C}\right)$ & 13.7 & 14.1 & 14.2 \\
Mean precipitation $(\mathrm{mm})$ & 645 & 565.6 & 421.6 \\
Prevailing wind direction & $\mathrm{W}$ & $\mathrm{SW}$ & $\mathrm{W}$ \\
\hline
\end{tabular}

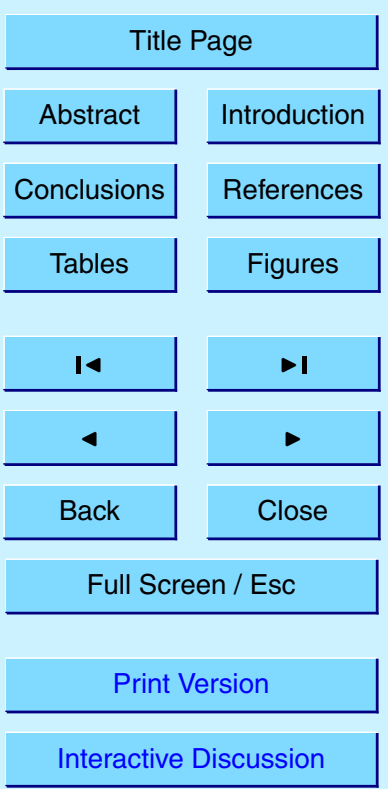


Table 2. PAH concentrations ( $\mathrm{ng} \mathrm{L}^{-1}$ ) in bulk deposition

\begin{tabular}{|c|c|c|c|c|c|c|c|c|}
\hline \multirow[b]{3}{*}{ ACE } & \multicolumn{2}{|c|}{ Le Havre } & \multicolumn{2}{|r|}{ Evreux } & \multicolumn{2}{|r|}{ Rouen } & \multicolumn{2}{|r|}{ NDG } \\
\hline & \multicolumn{2}{|c|}{$\begin{array}{c}\text { Mean (min-max) } \\
n=22\end{array}$} & \multicolumn{2}{|c|}{$\begin{array}{c}\text { Mean (min-max) } \\
n=21\end{array}$} & \multicolumn{2}{|c|}{$\begin{array}{c}\text { Mean (min-max) } \\
n=22\end{array}$} & \multicolumn{2}{|c|}{$\begin{array}{c}\text { Mean (min-max) } \\
n=21\end{array}$} \\
\hline & 2.12 & $(0.25-5.9)$ & 0.68 & $0.01-2.85)$ & 1.06 & $(<$ D.L. -5.02$)$ & 0.56 & $(0.13-1.18)$ \\
\hline $\mathrm{FL}$ & 3.19 & $(0.5-9.1)$ & 2.31 & $(<$ D.L. -6.71$)$ & 2.36 & (<D.L. $-\varepsilon$ & 1.95 & $(0.63-3.93)$ \\
\hline PHE & 19.6 & $(2.2-82.8)$ & 16.8 & $(0.23-69.6)$ & 8.01 & $(0.15-25.63)$ & 7.13 & (1.89-18.3) \\
\hline ANT & 0.61 & $(0.01-2.68)$ & 0.62 & $(<$ D.L.-2.69) & 0.31 & $(<$ D.L. -0.97$)$ & 0.22 & $(0.02-1.5)$ \\
\hline FTH & 23.9 & $(1.06-120.2)$ & 16.4 & $(0.55-58.4)$ & 9.08 & $(<$ D.L.-24.7) & 6.02 & $(1.36-26.2)$ \\
\hline PYR & 21.1 & (1.27-86.95) & 10.6 & $(0.36-32.5)$ & 6.76 & $(<$ D.L. -21.6$)$ & 5.22 & $(0.36-35.9)$ \\
\hline BAA & 5 & $(0.03-29.5)$ & 2.08 & $(0.07-7.91)$ & 1.82 & $(<$ D.L.-8.09) & 0.98 & $(<$ D.L. -7.35$)$ \\
\hline $\mathrm{CHR}$ & 14.3 & $(0.31-59.9)$ & 4.51 & (<D.L.-15.2) & 3.78 & $(<$ D.L. -13.4$)$ & 3.11 & $(<$ D.L.-25.5) \\
\hline BBF & 13.5 & $(0.1-76.0)$ & 4.96 & $(0.06-20.1)$ & 3.33 & $(0.06-12.6)$ & 2.64 & $(0.34-17.6)$ \\
\hline BKF & 5.6 & $(0.04-37.6)$ & 2.18 & $(0.01-10.4)$ & 1.52 & $(0.01-6.76)$ & 1.01 & $(0.1-5.99)$ \\
\hline BAP & 5.8 & $(0.01-76.0)$ & 2.34 & $(<$ D.L.-12.4) & 1.70 & $(<$ D.L. -9.78$)$ & 1.10 & $(0.01-10)$ \\
\hline DBA & 1.30 & $(<$ D.L. -13$)$ & 0.68 & $(<$ D.L.-4.04) & 0.31 & $(<$ D.L.-1.64) & 0.32 & $(<$ D.L.-2.12) \\
\hline BGP & 12.3 & $(0.1-83.1)$ & 4.34 & $(0.05-19.3)$ & 2.72 & $(0.05-12.4)$ & 2.04 & $(<$ D.L. -16.5$)$ \\
\hline IND & 5.9 & $(<$ D.L. -35.6$)$ & 2.50 & $(<$ D.L. -12.1$)$ & 1.14 & $(<$ D.L. -4.47$)$ & 1.36 & $(<$ D.L. -9.79$)$ \\
\hline$\Sigma \mathrm{PAH}$ & 141.21 & $(8.7-672)$ & 77.79 & $(3.45-234)$ & 49.61 & $(3.45-129)$ & 37.95 & $(9.59-184)$ \\
\hline$\Sigma \mathrm{PAH}_{\mathrm{CARC}}$ & 37.01 & $(0.17-237)$ & 14.73 & $(0.52-56.5)$ & 9.82 & $(0.85-39.4)$ & 7.42 & $(0.49-52.9)$ \\
\hline
\end{tabular}

acenaphthene (ACE), fluorene (FL), phenanthrene (PHE), anthracene (ANT), fluoranthene $(\mathrm{FTH})$, pyrene (PYR), benz(a)anthracene (BAA), chrysene $(\mathrm{CHR})$, benzo(b)fluoranthene $(B B F)$, benzo(k)fluoranthene (BKF), benzo(a)pyrene (BAP), dibenz(a,h)anthracene (DBA), benzo(g,h,i)perylene (BGP), indeno(1,2,3-cd)pyrene (IND).

PAHCARC: BAA, BBF, BFK, BAP, DBA and IND (IARC, 2001)
ACPD

2, 1351-1369, 2002

\section{Atmospheric deposition of PAHs in the Seine Estuary, France}

A. Motelay-Massei et al.

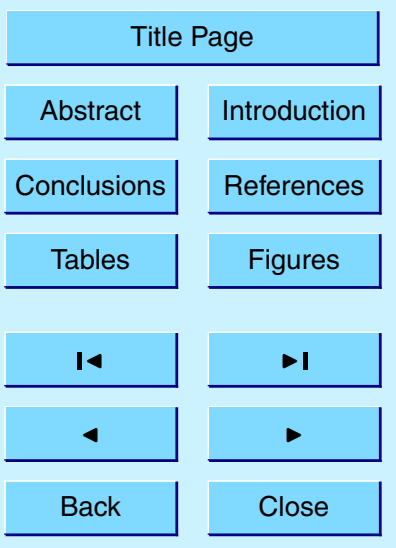

Full Screen / Esc

Print Version

Interactive Discussion 


\section{ACPD}

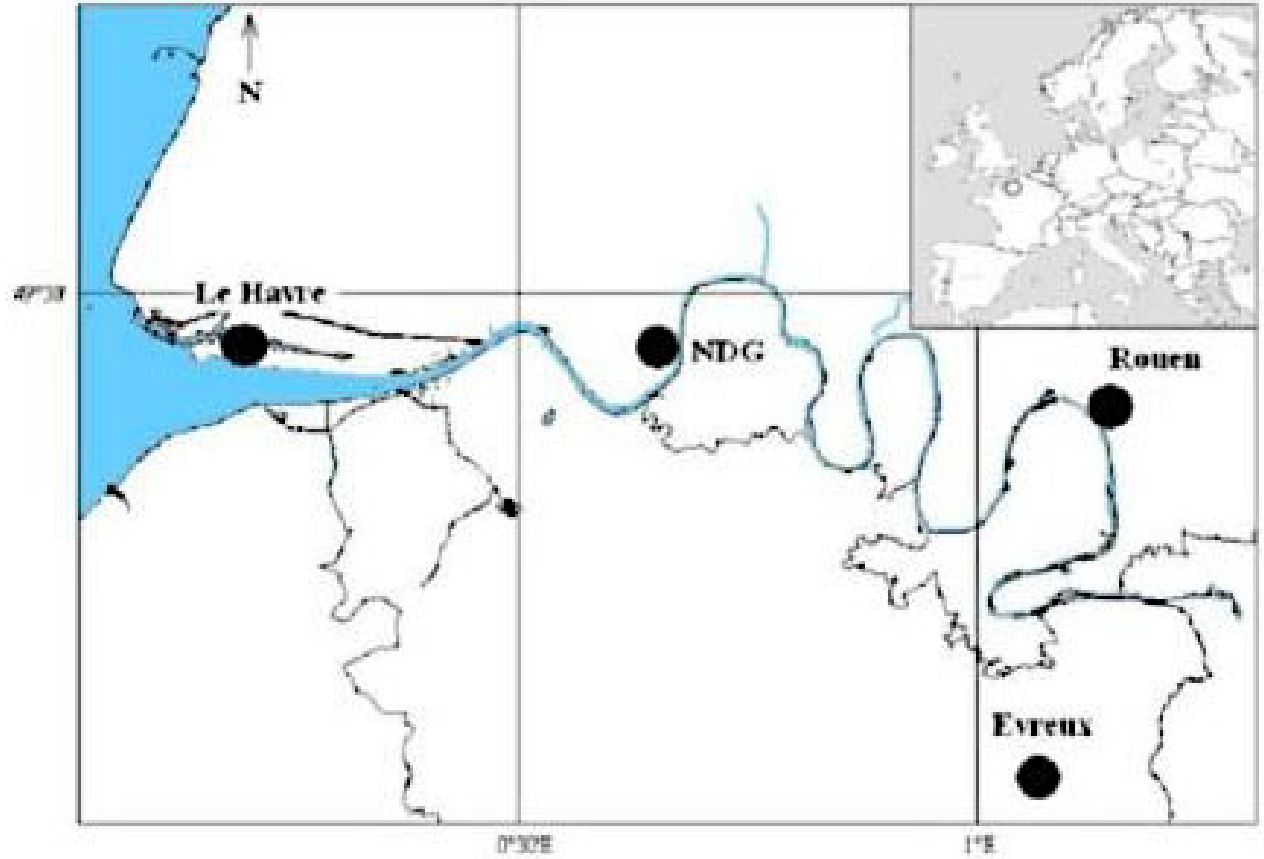

2, 1351-1369, 2002

\section{Atmospheric deposition of PAHs in the Seine Estuary, \\ France}

\section{A. Motelay-Massei et al.}

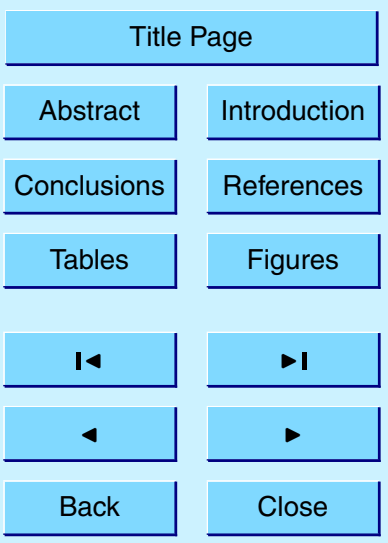

Fig. 1. Location of the monitoring sites in the Seine Estuary.

Full Screen / Esc

\section{Print Version}

Interactive Discussion

(C) EGS 2002 


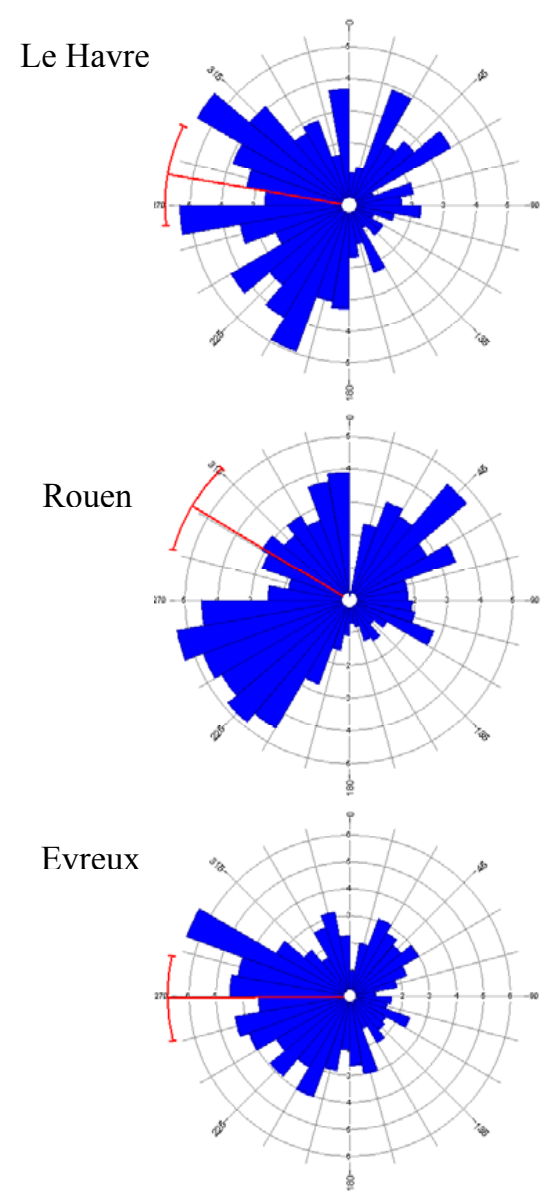

Fig. 2. Compass roses related to the sampling sites.

\section{ACPD}

2, 1351-1369, 2002

Atmospheric deposition of PAHs in the Seine Estuary,

France

A. Motelay-Massei et al.

\begin{tabular}{c|c}
\multicolumn{2}{c}{ Title Page } \\
\hline Abstract & Introduction \\
\cline { 1 - 1 } Conclusions & References \\
\cline { 1 - 1 } Tables & Figures \\
\hline
\end{tabular}

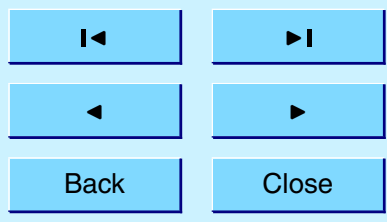

Full Screen / Esc

Print Version

Interactive Discussion

(C) EGS 2002 


\section{ACPD}

2, 1351-1369, 2002

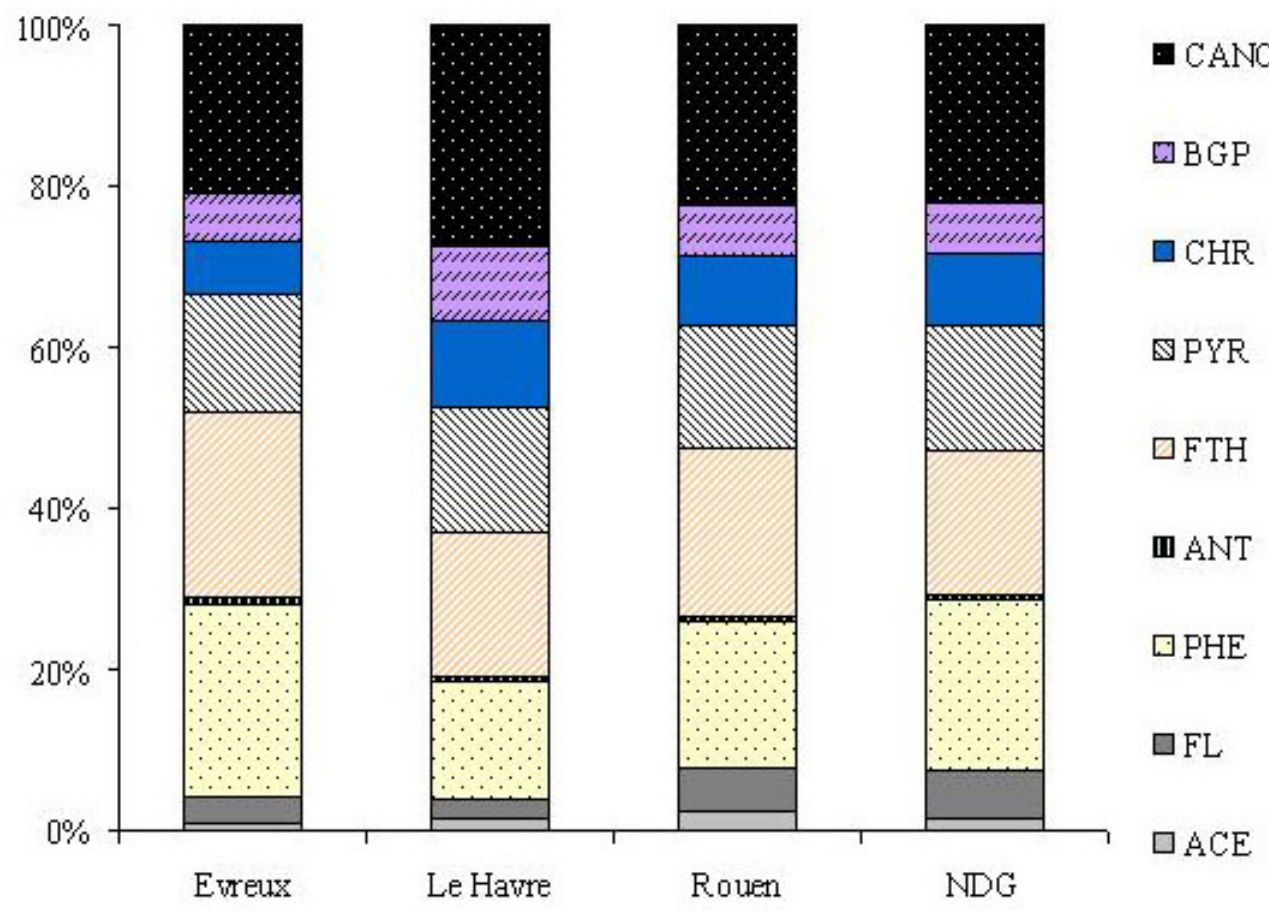

Atmospheric deposition of PAHs in the Seine Estuary, France

A. Motelay-Massei et al.

Title Page

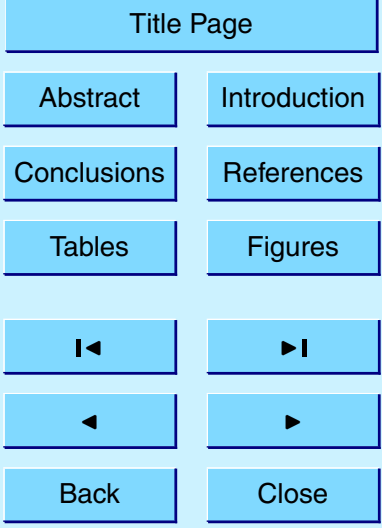

Full Screen / Esc

Fig. 3. Mean contribution of compounds to $\Sigma P A H$.

Print Version

Interactive Discussion

(C) EGS 2002 


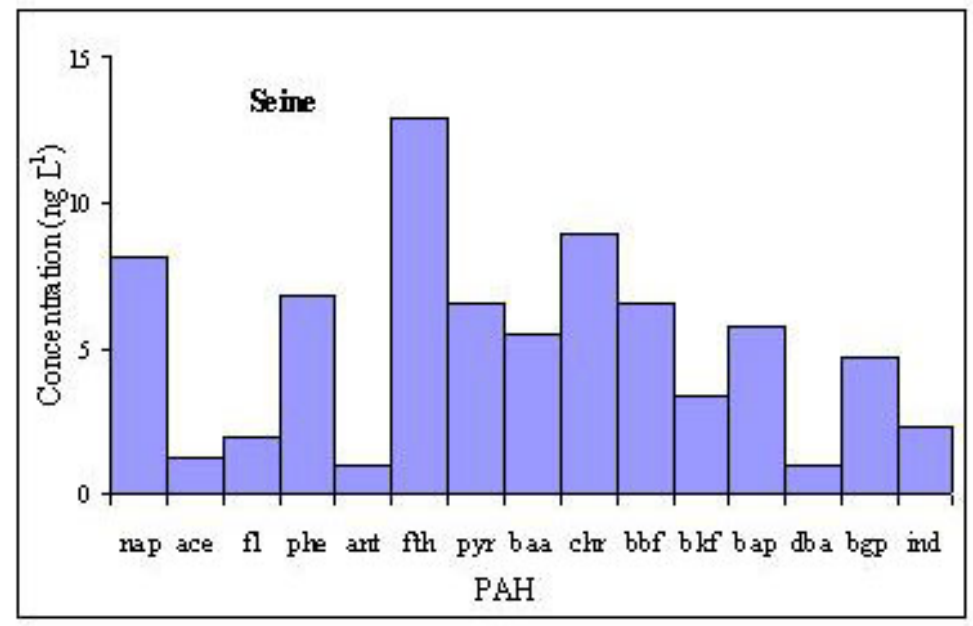

\section{ACPD}

$2,1351-1369,2002$

\section{Atmospheric deposition of PAHs in the Seine Estuary, \\ France}

A. Motelay-Massei et al.

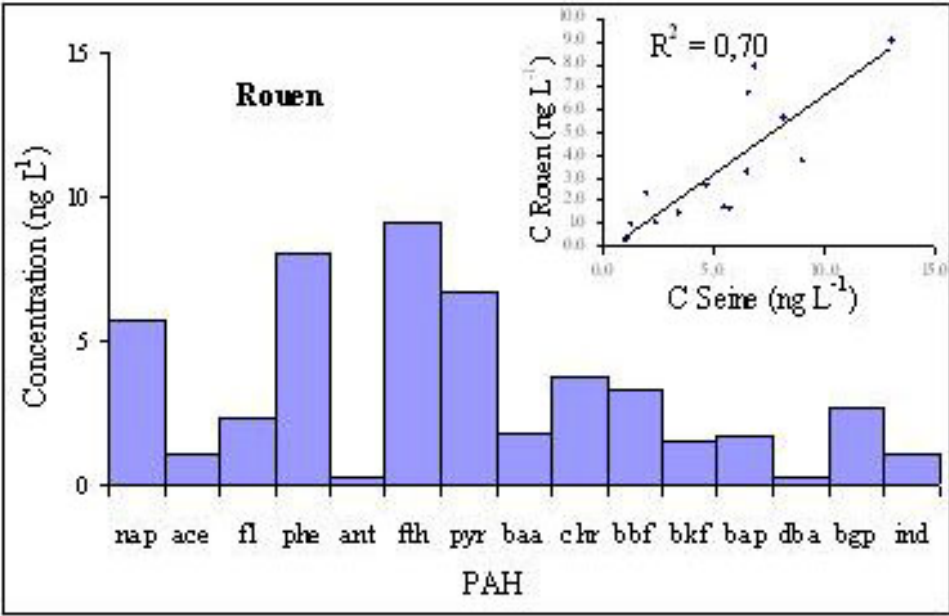

Title Page

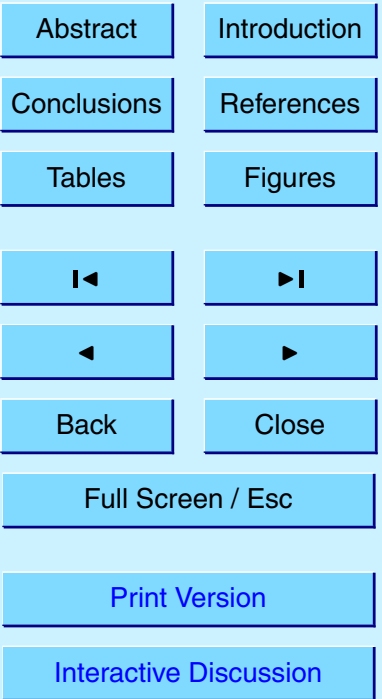

Fig. 4. Average signatures of the concentrations of PAHs in bulk deposition and surface water. 


\section{ACPD}

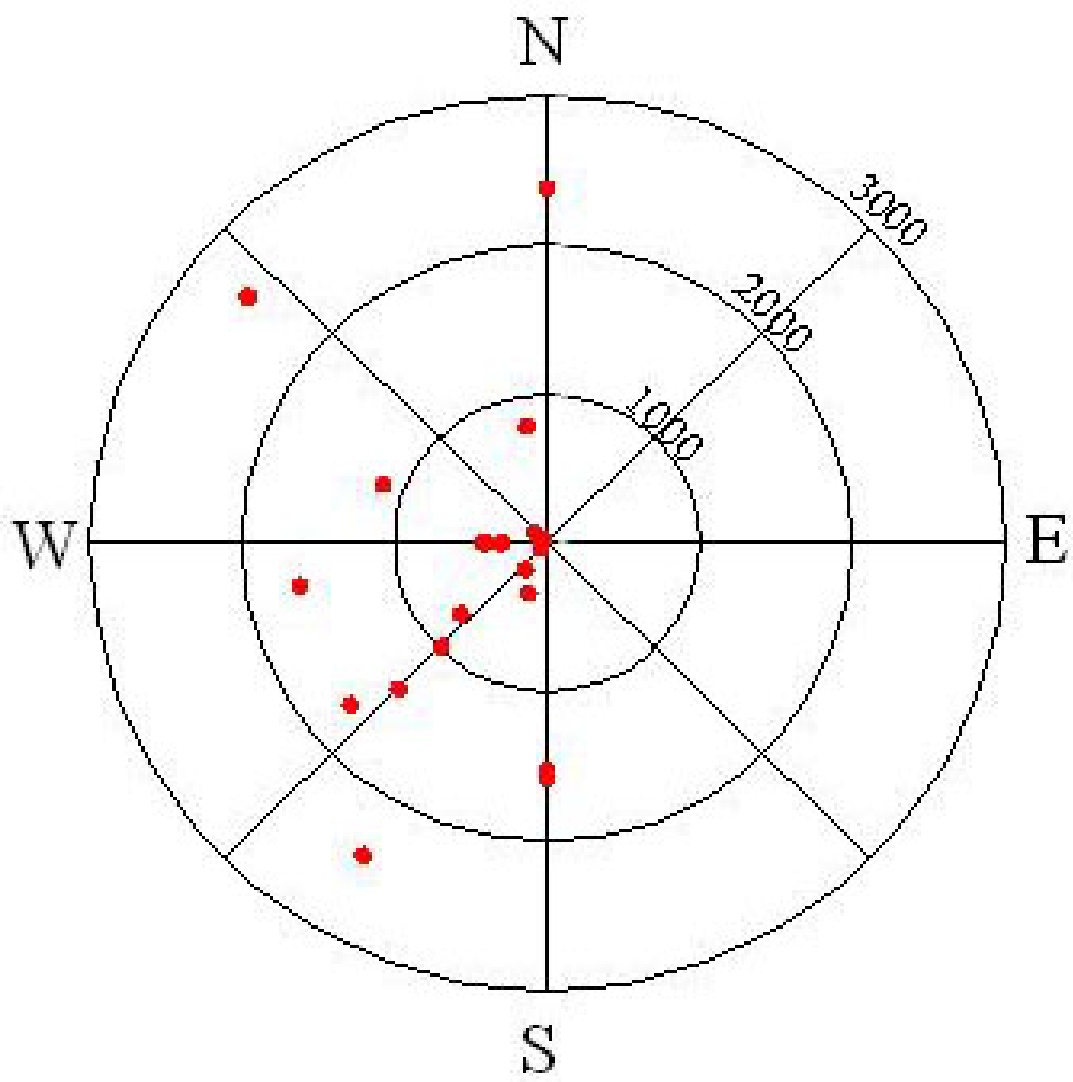

Fig. 5. $\mathrm{PAH}$ flux (ng m${ }^{-2}$ week $^{-1}$ ) according to wind direction at Evreux.
$2,1351-1369,2002$

\section{Atmospheric deposition of PAHs in the Seine Estuary, \\ France}

A. Motelay-Massei et al.

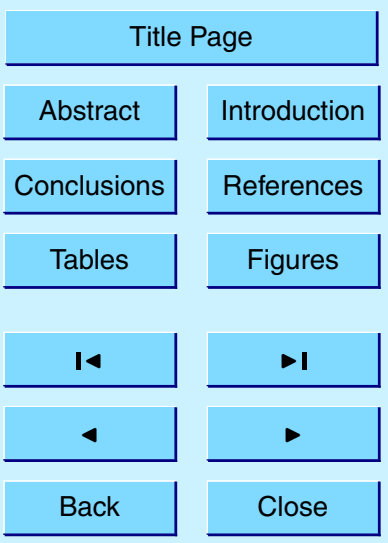

Full Screen / Esc

Print Version

Interactive Discussion

(C) EGS 2002 


\section{ACPD}

$2,1351-1369,2002$



Fig. 6. Bulk deposition fluxes of the sum of 14 PAH species. Segregated by heating and non-heating seasons. Solid lines are averages.
Atmospheric deposition of PAHs in the Seine Estuary,

France

A. Motelay-Massei et al.

Title Page

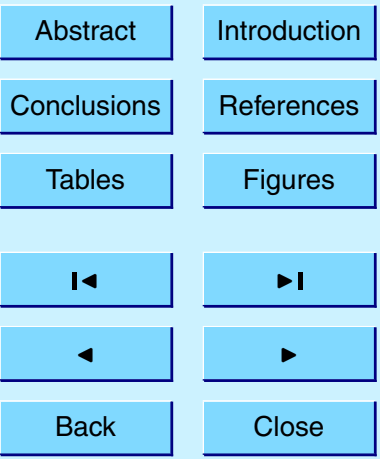

Full Screen / Esc

Print Version

Interactive Discussion

(C) EGS 2002 